\title{
CAT AND DOG CONCEPTS AS COMPONENTS OF THE ENGLISH WORLDVIEW
}

\section{КОНЦЕПТИ САT I DOG ЯК СКЛАДНИКИ АНГЛОМОВНОЇ КАРТИНИ СВІТУ}

\section{Olga Novikova ${ }^{1}$}

DOI: https://doi.org/10.30525/978-9934-26-051-3-5

Abstract. The subject of the study is the linguistic objectification of the concepts of CAT and DOG in lexicographic sources, due to the national culture and mentality of English speakers (The British). The paper aims at identifying the objectification features of CAT and DOG concepts in the British linguoculture. The significance of CAT and DOG concepts is motivated by the degree of verbal explication and their value in English culture. In our work, the reconstruction of English world view fragments, marked by CAT and DOG concepts, was carried out on the material of lexical units. The purpose and problem is due to the use of the following methods: general scientific (abstraction, generalization, formalization, induction, deduction), empirical-theoretical (analysis, synthesis) and special (lexical-semantic analysis - to clarify the semantic potential of the concept name; dictionary definition method - to clarify the semantics of possible verbalizers of the concept, determine its name and description of the conceptual component; elements of etymological analysis - to explain the content of the concept verbalizer. Verbal nominations, representing CAT and DOG concepts, are interpreted as fixators of knowledge about objects, explicitly expressed in language. CAT and DOG concepts have a concretesubject character, they correlate with the objective reality - a discrete, objectively available material object of reality. As a result of the definitive analysis and based on the definition of the nominative token cat and dog, we distinguished 12 generalized meanings that form the denotation CAT concept and 14 generalized meanings that produce the denotation of DOG concept. The conceptual basis of CAT and DOG concepts is expanded with

${ }^{1}$ Lecturer at Faculty of Ukrainian and Foreign Philology and Study of Art, Oles Honchar Dnipro National University, Ukraine 
the help of additional semantic features, taking into account the cognitivesemantic analysis of synonymous equivalents of the nouns cat and dog.

\section{1. Ветуп}

Студіювання концептів як основних конструювальних одиниць картини світу дає змогу отримати інформацію про світосприйняття народу - носія мови. Концепти CAT і DOG як ментальні сутності, що відбивають знання про світ і корелюють 3 предметами, процесами та явищами дійсності, маркують фрагменти національної мовної картини світу. Значущість аналізованих концептів умотивована ступенем вербальної експлікації та їхнім ціннісним значенням в англійській культурі. Концепт $є$ значущим для культури, тому мова максимально структурує той чи той концепт лексично й граматично. У межах нашого дослідження реконструкція фрагментів англомовної картини світу, маркованих концептами CAT i DOG, проводилася на матеріалі різних лексичних одиниць англійської мови. Актуальність нашого дослідження зумовлена нагальною потребою задовольнити запити сучасної когнітивної науки щодо вирішення таких фундаментальних проблем, як з'ясування особливостей представлення знань про світ і способи їх концептуалізації в мові. Незважаючи на виникнення низки наукових праць, присвячених розгляду концептів у тій чи тій лінгвокультурі, останні ще залишаються маловивченою проблемою. Мета роботи полягає у виявленні особливостей об’єктивації концептів CAT і DOG в англійській лінгвокультурі. Наше дослідження присвячено аналізові етимології слів-номінантів концептів CAT i DOG з детальним розглядом специфіки вербалізації концептів CAT і DOG лексичними одиницями.

\section{2. Етимологічні характеристики концептів $C A T$ i $D O G$}

Для опису концептів вважаємо за необхідне передусім виявити їх передконцептуальні властивості за даними історії мови. Структура концепту, на думку Ю. С. Степанова, має все, що «належить будові поняття; з іншого боку, усе, що робить концепт фактом культури - вихідна форма (етимологія); стиснута до основних ознак змісту історія; сучасні асоціації; оцінки та ін.» [4, с. 43]. Дослідження концептів САТ i DOG в англійській лінгвокультурі має базуватися на докладному вивченні етимології слів-номінантів концепту, чиї семантичні ознаки да- 
ють змогу глибше зрозуміти природу концептів. У результаті аналізу словників різних історичних періодів можна «зробити важливі висновки про зміни, що відбулися в лексичних засобах, які брали участь у репрезентації концепту» [5, с. 42].

На початку розглянемо етимологічні особливості концепту САТ. Згідно зі зведеними даними етимологічних словників англійської мови вживання лексеми cat уперше зафіксовано на початку VI ст. Існує думка, що давньоанглійська ЛО catt походить від латинської ЛО cattus. Було висловлено припущення, що ЛО cattus пов'язана 3 давньоєгипетськими коптами $y$ šau (представники найдавнішої релігіозної спільноти християн), «tomcat» або слово жіночого роду з суфіксом $-t$.

Серед науковців-етимологів також існує думка, що латинське слово cattus може походити з афро-азіатських мов. Нубійське слово kaddîska «wildcat» i kadīs є можливими джерелами походження сучасного слова cat. Нубійська ЛО kaddîska може бути запозичене з арабської мови

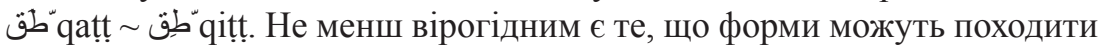
від давньогерманського слова, запозиченого у латинську мову, а звідти у грецьку, сирійську та арабську.

ЛО cat може походити з германської та північноєвропейської мов i, врешті-решт, може буде запозичене з уральської мови gádfi, «female stoat», і з угорської hölgy, «stoat»; також $є$ припущення, що лексема cat сягає своїм корінням протоуральської мови käd’wä, «female (of a furred animal)».

У словникових статях наявна інформація щодо походження лексеми cat, яка є вербалізатором концепту САТ. Деякі дослідники допускають, що в основі слів різних індоєвропейських мов, що позначають кішку, лежить праіндоєвропейський корінь «* kat-», від якого утворилися дієслова в індоєвропейських мовах, які означають «котитися», від яких пізніше виникли назви дитинчат невеликих тварин. Інші дослідники вважають такий зв'язок вторинним.

Звуконаслідувальними, близькими до англійського дієслова meow, $\epsilon$ назви кішки в давньоєгипетській (mj.w) і китайській мовах (māo).

Англійська лексема puss та похідні лексеми pussy i pussycat датовані ще XVI ст. Ці слова є похідними з голандської лексеми poes або з німецької puuskatte, які у свою чергу мають зв'язок зі шведською ЛО kattepus, або ж норвежською ЛО pus, pusekatt. 
Етимологічні джерела надають інформацію про лексему на позначення кота tom чи tomcat, а щодо позначення кішки простежуємо лексему queеn, особливо в тих контекстах, які пов'язані з розведенням кішок або породою кішок. На початку періоду сучасної англійської мови (Early Modern English) з'явилась ЛО на позначення маленького кошеняти, сучасне слово kitten було замінено на те, що зараз є застарілим catling.

Отже, посилаючись на інформацію лексикографічних джерел, доходимо висновку, що етимоном лексеми cat (n.) $\epsilon$ «domestic cat» (від латинського слова * cattus).

Для того, щоб виявити етимологічні особливості концепту DOG, потрібно простежити розвиток лексеми $d o g$ та іï появу в сучасній англійській мові, оскільки лексема $\operatorname{dog} є$ вербалізатором концепту DOG.

ЛО $\operatorname{dog}$ уперше зустрічається у давньоанглійській мові, але є менш вживаним, ніж синонім hound (більш формальний та літературний), хоча, можливо, лексема $d o g$ була поширеним у нелітературному та розмовному контекстах. На відміну від лексеми hound, яка бере свій початок у ранніх германських мовах, а отже, має багато спільних рис 3 іншими європейськими мовами - німецькою hund, голландською hond тощо, слово $\operatorname{dog}$ використовували для позначення тварин (які мають закінчення на $-\mathrm{g}$ ), воно не мало чіткого походження чи спільних рис в інших європейських мовах. До таких назв тварин, які позначала лексема dog уналежнені hog (бик), stag (олень), pig (свиня), еarwig (щипавка).

На основі етимологічних джерел виявлено, що сучасна лексема $\operatorname{dog}$ походить від давньоанглійського docga. ЛО docga була рідкісним явищем і позначала представника сімейства собачих «саnine». У періоді середньоанглійської мови docga вживалося як образа щодо людини. Походження цього слова залишається однією з великих загадок англійської етимології.

ЛО docga витіснила давньоанглійське hund (загальне германське та індоєвропейське слово, від кореня * kwon-) до XVI ст. і згодом було використане в багатьох континентальних мовах (у французькій мові dogue (XVI ст.), у данській мові dogge, у німецькій мові Dogge (XVI ст.)).

Поширена іспанська лексема на позначення собаки реrro є загадковим явищем невідомого походження, можливо, вона пов'язана 3 іберійською мовою. Низка слов'янських слів на позначення собаки 
(у старослов'янській мові pisu, у польській мові pies, у сербськохорватських мовах pas) також залишається невідомого походження.

У Англії в XIV ст. ЛО hound (from Old English hund) була загальною назвою для всіх домашніх собак, а ЛО $\operatorname{dog}$ була пов'язана з породами собак, наприклад, тими, що нагадували сучасних бульдога та мастифа. До XVI ст. ЛО $d o g$ стала загальновживаною, а hound використовували щодо порід собак для полювання. В XVI ст. ЛО $d o g$ була розповсюдженою в багатьох європейських мовах.

У 1200 році вперше зафіксовано випадок вживання лексеми $d o g$ зі значенням «a mean, worthless fellow, currish, sneaking scoundrel». 3 наведеного тлумачення можна побачити, що ЛО $\operatorname{dog}$ вживалася у функції звертання та мала негативну конотацію, оскільки означала нікчемну та негідну людину. Починаючи з 1610-х років, ЛО $\operatorname{dog}$ означала «rakish man, especially if young, a sport, a gallant man». У 1930-х роках лексема $d o g$ почала використовуватися у сленговому значенні «ugly woman», а з 1950-х років з'являється значення «sexually aggressive man». Простеживши етимологію лексеми $d o g$, потрібно зазначити, що етимоном досліджуваної лексеми є «саnine» (від давньоанглійського слова * docga).

\section{3. Специфіка імені концепту $\boldsymbol{C A T}$}

Вважаємо, що аналіз ядра концепту починається з виявлення базових лексем, які репрезентують його у мові за такими критеріями, як частотність вживання, достатній рівень абстрактності значення, загальновживаність. Аналіз словникових дефініцій дав змогу виокремити ядерні вербалізатори концепту САТ та основні способи прямої номінації в англійській мові.

В онлайн словнику Macmillan Dictionary наявні лише два визначення, у яких кішка представлена як домашня тварина або дика тварина, що $\epsilon$ подібною до кішки, наприклад, лев або тигр. Слід зазначити, що в цьому випадку для лексеми cat домінантними $€$ семантичні елементи an animal with soft fur, a long thin tail, and whiskers, that people keep as a pet, а вторинними - a wild animal that looks like a large cat.

На відміну від попереднього словника, в Oxford English Dictionary наявні три значення cat. Цікаво зазначити, що ЛО cat набуває інших вторинних семантичних характеристик, зокрема, malicious or spiteful woman, jazz enthusiasts, short tapered stick used in the game of tipcat. 
Автори Oxford Advanced Learner's Dictionary підкреслюють хижість тварини cat.

У словнику Cambridge International Dictionary of English звертаємо увагу на те, що для аналізованої лексеми cat домінантними є семантичні елементи a small animal with fur, four legs, and a tail that is kept as a pet, а вторинними - a large, wild animal that is related to the cat.

В Longman Dictionary of Contemporary English спостерігаємо аналогійну ситуацію щодо домінантних і вторинних семантичних елементів, як представлено в Cambridge International Dictionary of English, Oxford Advanced Learner's Dictionary ma Macmillan Dictionary.

Щодо Collins English Dictionary, зазначимо, що перша дефініція, хоча й трохи подібна до попередніх визначень, проте є відмінною від них, оскільки домінантна семантична ознака cat представлена у такий спосіб: a small domesticated feline mammal, Felis catus (or domesticus), having thick soft fur and occurring in many breeds in which the colour of the fur varies greatly. Вторинними є такі ознаки, як woman who gossips maliciously; a man; guy; heavy tackle for hoisting an anchor to the cathead; a short sharp-ended piece of wood used in the game of tipcat; a slang word for vomit; the leaves of the shrub Catha edulis.

Досить показовими є інтерпретації лексеми cat в Merriam-Webster. Домінантною семантичною ознакою є а carnivorous mammal (Felis catus) long domesticated as a pet and for catching rats and mice, серед вторинних наявні аналогійні ознаки, які зафіксовано в попередніх випадках. Серед вторинних ознак спостерігаємо a player or devotee of jazz, slang word for guy, a malicious woman, a strong tackle used to hoist an anchor to the cathead of a ship.

Під час дослідження лексеми cat серед усіх значень виокремлюємо основні та периферійні, що визначаються на основі частотного критерія спільності значень у всіх досліджуваних словниках. За допомогою дефініцій 7 англомовних тлумачних словників ми отримали 12 узагальнених значень, що складають денотат досліджуваного концепту САТ. Основним значенням іменника «саt», що актуалізує концепт САТ в англійській мові, є те значення, що найчастіше зустрічається в словникових дефініціях: маленька тварина з хутром, чотирма ногами та хвостом, яку тримають як домашню тварину (a small animal with fur, four legs, and a tail that is kept as a pet). 
До периферійних уналежнимо значення, які є менш уживаними у словникових статтях.

Периферія 1 (зазначення в 7 словниках) містить одне значення: cat - будь-який великий представник сімейства котячих, наприклад лев або тигр; будь-який дикий котячий ссавець з роду Felis, наприклад рись або пантера, що нагадує домашню кішку (any of the larger felines, such as a lion or tiger; any wild feline mammal of the genus Felis, such as the lynx, resembling the domestic cat).

Периферія 2 (у 3 словниках) містить два значення: a) cat - сленговий вираз на позначення хлопця або чоловіка (slang a man; guy); б) cat - неформальне визначення жінки, яку вважають пліткаркою (informal A malicious or spiteful woman).

Периферія 3 (у 2 словниках) містить одне значення: cat - джазовий музикант (a player or devotee of jazz).

Периферія 4 (у 2 словниках) має дві дефініції: a) cat - міцне приладдя, яке використовують для підняття якоря (a strong tackle used to hoist an anchor to the cathead of a ship; б) cat - короткий гострий шматок дерева, який використовується під час вуличної гри (a short sharp-ended piece of wood used in the game of tipcat).

Периферія 5 (у 2 словниках) охоплює визначення: cat - комп'ютерна осьова томографія (computed axial tomography).

Периферія 6 (в 1 словнику) містить три дефініції: a) cat - сленгове слово «блювота» (a slang word for vomit); б) пристрій каталітичний перехідник (catalytic converter); в) cat - листя дерева Catha edulis, які жують, як тютюн, або використовують для приготування чаю; ця рослина надає відчуття ейфорії (the leaves of the shrub Catha edulis which are chewed like tobacco or used to make tea; has the effect of a euphoric stimulant).

Отже, поняттєвим складником концепту САТ є розуміння кота як невеликого ссавця сімейства котячих Felis catus, який має густе м'яке хутро та утримується як домашня тварина. Ядро представлене визначенням a carnivorous mammal (Felis catus) long domesticated as a pet and for catching rats and mice; до ближньої периферійної зони уналежнено значення a man; guy; malicious or spiteful woman; a player or devotee of jazz; до дальньої - a short sharp-ended piece of wood used in the game of tipcat; a strong tackle used to hoist an anchor to the cathead of a ship; 
the leaves of the shrub Catha edulis; slang word for vomit; computed axial tomography.

Проаналізувавши словникові дефініції лексеми cat, можемо констатувати, що ЛО cat - багатозначна (має від 3 до 12 значень). Крім того, за частотністю використання лексеми cat у словникових статтях встановили іiі семантичну структуру, виокремили компоненти - дефініційні репрезентанти імені концепту CAT: «small domesticated feline mammal», «any of the larger felines», «woman who gossips maliciously», «a man, guy», «a jazz musician or enthusiast». Отже, словники, які представляють семантичну структуру слова - cat, демонструють різні ЛСВ, що містять однотипні та різнотипні тлумачення; водночас зауважимо, що ядерним компонентом семантики лексеми - cat потрібно вважати найчастотніші ЛСВ: «small domesticated feline mammal», «any of the larger felines».

Для повного розкриття поняттєвого складника концепту САТ, потрібно звернутися до аналізу визначень синонімів номінативної одиниці cat. Ю. С. Степанов зазначає, що синоніми є засобами номінації концепту, коли вони уналежнені до одного денотата або коли позначають одне поняття [4].

Ядром концепту САТ, яке найкраще відбиває семантику ключового слова, що називає цей концепт, є ЛО cat. Основними способами номінації зазначеного концепту в англійській мові є іменники на зразок kitty, kitten, mouser, puss, pussy, tom, grimalkin, faline. Кожна сема семантеми cat, що є реалізацією поняттєвого складника концепту САТ, може виявлятися в синонімічному ряді. Крім ядерного слова, кожний синонім відіграє роль у репрезентації концепту, слугує його додатковим характеризувальним складником. У межах нашого дослідження за допомогою англомовних словників-тезаурусів на кшталт Roget's II The New Thesaurus, Collins English Dictionary, Merriam-Webster Online Dictionary and Thesaurus, Oxford Dictionaries Online, Wordsmyth Dictionary та The Synonym Finder виокремлено синонімічні лексеми, що вербалізують концепт САТ і входять до його номінативного поля.

У тезаурусі Роже (Roget's II The New Thesaurus) концепт CAT представлено такими одиницями: ядро - puss, kitten, tom; ближню периферію grimalkin, mouser, feline; крайню периферію - lion, tiger, leopard, cheetah, panther, puma, jaguar, wildcat, bobcat, catamountain, lynx [10, c. 338]. 
The Synonym Finder містить такі одиниці концепту CAT: ядро - kitty, kitty-cat, puss, pussy, pussycat,mouser, alley cat, tom, tomcat, queen, tabby зі значенням «feline mammal usually having thick soft fur and no ability to roar: domestic cats; wildcats»; ближню периферію - gossip, gossiper, gossipmonger, rumormonger, rumourmonger, newsmonger як синоніми до слова cat зі значенням «a spiteful woman gossip». Крім того, ближню периферію також представлено: bozo, guy, hombre зі значенням «an informal term for a youth or man».

Виявлені синонімічні номінанти концепту САТ дали змогу представити номінативне поле зазначеного концепту у такий спосіб: ядро концепту САТ представлене лексемою cat; ближня периферія охоплює такі одиниці: feline, puss, kitten, bobcat, cougar, leopard, lion, lynx, ocelot, panther, tiger, wildcat; до дальньої периферії уналежнено gossip, scandalmonger; gossiper, gossipmonger, rumormonger, rumourmonger, newsmonger, fellow, guy, player, musician, bozo, guy, hombre.

\section{4. Специфіка імені концепту $D O G$}

Дефініційний аналіз номінативної лексеми концепту є одним із прийомів концептуального аналізу та допомагає визначити поняттєвий складник концепту, оскільки найосновніші ознаки означуваного предмета або явища містяться у дефініціях лексеми-імені концепту. Саме тому у нашому дослідженні представлено визначення лексеми $d o g$, зафіксовані в тлумачних словниках.

У словнику Macmillan Dictionary виявлено п'ять визначень лексеми $\operatorname{dog}$. Слід зазначити, що для названої лексеми домінантними є семантичні елементи an animal kept as a pet, for guarding buildings, or for hunting. ЛО dog означає домашню тварину, яку утримують для охорони будинку або полювання. Вторинні ознаки лексеми dog - a male dog or a male animal that belongs to the same group of animals as dogs, such as a male wolf or fox; someone who is not attractive, especially a woman; someone who gives information about people to the police or to another authority.

В Oxford English Dictionary у лексеми dog наявна домінантна семантична ознака a domesticated carnivorous mammal that typically has a long snout, an acute sense of smell, non-retractable claws, and a barking, howling, or whining voice. Як бачимо, порівнюючи з попереднім прикла- 
дом, є суттєві відмінності у семантичному аспекті, зокрема, dog представлено як domesticated carnivorous mammal. Вторинними ознаками $\epsilon$ informal an unpleasant, contemptible, or wicked man; an unattractive woman; an informer or traitor; a thing of poor quality; a mechanical device for gripping.

В Oxford Advanced Learner's Dictionary значення лексеми dog констатується низкою елементів з багатозначною семантикою. По-перше, домінантною семантичною ознакою $\mathrm{\epsilon}$ an animal with four legs and a tail, often kept as a pet or trained for work, for example hunting or guarding buildings; багатозначності лексема $\operatorname{dog}$ набуває у вторинних контекстах: a thing of low quality; a failure; an offensive way of describing a woman who is not considered attractive; used, especially after an adjective, to describe a man who has done something bad; grey hound racing.

У словнику Cambridge International Dictionary of English домінантне семантичне значення досліджуваної лексеми представлено у такий споcіб: a common animal with four legs, especially kept by people as a pet or to hunt or guard things; вторинне значення - a man who is unpleasant or not to be trusted; an investment, company, or product that will probably fail; a product that has a small share of a market that has a lowrate of growth.

У словнику Longman Dictionary of Contemporary English первинні та вторинні семантичні ознаки є подібними до тих, що представлені у словнику Oxford Advanced Learner's Dictionary. Первинна домінувальна семантична ознака лексеми $d o g$ - a common animal with four legs, fur, and a tail, а вторинна - an offensive word meaning an unattractive woman; informal not polite an offensive word for an unpleasant or dishonest man; something that is of very poor quality.

Словник Collins English Dictionary має низку визначень лексеми $d o g$. Серед домінантних семантичних ознак потрібно зазначити a domesticated canine mammal, Canis familiaris, occurring in many breeds that show a great variety in size and form. Вторинні ознаки представлені у такий спосіб: a mechanical device for gripping or holding; a fellow; chap; a man or boy regarded as unpleasant, contemptible, or wretched; a male friend: used as a term of address; an unattractive or boring girl or woman; something unsatisfactory or inferior.

У словнику Merriam-Webster нами виявлено, що домінувальною семантичною ознакою є a highly variable domestic mammal (Canis 
familiaris) closely related to the gray wolf, а вторинними ознаками $є$ такі: a worthless or contemptible person; any of various usually simple mechanical devices for holding, gripping, or fastening that consist of a spike, bar, or hook; uncharacteristic or affected stylishness or dignity; an investment not worth its price; an undesirable piece of merchandise; an unattractive person.

Під час дослідження лексеми $d o g$ серед усіх значень виокремлюємо основні та периферійні, що визначаються на основі частотного критерія спільності значень у всіх досліджуваних словниках. За допомогою дефініцій 7 англомовних тлумачних словників ми отримали 14 узагальнених значень, що складають денотат досліджуваного концепту DOG. Основним значенням лексеми $d o g$, що актуалізує концепт DOG в англійській мові, є те значення, що найчастіше зустрічається в словникових дефініціях: тварина з чотирма лапами, хутром і хвостом, різної породи та розміру. Цих тварин утримують як домашніх або використовують для охорони та полювання (a common animal with four legs, fur, and a tail. Dogs are kept as pets or trained to guard places, find drugs etc). До периферійних уналежнимо значення, які є менш уживаними у словникових статтях.

Периферія 1 (зазначення в 7 словниках) складається 3 двох значень: a) dog - тварина, яку утримують як домашню, для охорони будівель або для полювання (an animal kept as a pet, for guarding buildings, or for hunting; б) dog - тварина-самець, що належить до тієї ж групи тварин, що і собаки, наприклад, вовк або лисиця (a male dog or a male animal that belongs to the same group of animals as dogs, such as a male wolf or fox).

Периферія 2 (у 6 словниках) містить дві дефініції: a) dog - неприємна, презирлива, зла людина (informal an unpleasant, contemptible, or wicked man); б) dog - неприваблива жінка (an unattractive woman).

Периферія 3 (у 5 словниках) визначає: $\operatorname{dog}$ - річ дуже низької якості (a thing of low quality).

Периферія 4 (у 2 словниках) має одну дефініцію: dog - інформатор або зрадник (an informer or traitor).

Периферія 5 (у 2 словниках) містить одне визначення: $\operatorname{dog}-$ інвестиція, компанія чи продукт, які, ймовірно, не матимуть успіху (an investment, company, or product that will probably fail). 
Периферія 6 (у 1 словнику) охоплює визначення: $\operatorname{dog}$ - механічний пристрій для утримування, наприклад, однієї з осьових прорізів, за допомогою яких зубчасті колеса або вали, задіяні для передачі крутного моменту (a mechanical device for gripping or holding, esp one of the axial slots by which gear wheels or shafts are engaged to transmit torque).

Унаслідок зіставлення словникових дефініцій постає, що ЛО $d o g$ - багатозначна (воно має від 3 до 14 значень) та налічує чимало лексико-семантичних варіантів (ЛСВ), зокрема: «a domesticated carnivorous mammal», «a wild animal of the dog family», «an unpleasant, contemptible, or wicked man», «an unattractive woman», «a fellow; chap». Дефініційними репрезентантами імені концепту DOG $\epsilon$ «domesticated canine mammal», «an offensive way of describing a woman who is not considered attractive», «a worthless or contemptible person», «something that is of very poor quality». Ядерним компонентом семантики лексеми $d o g$ вважаємо такі найчастотніші ЛСВ: «a domesticated canine mammal», «any other carnivore of the family Canidae», «an unattractive or boring girl or woman».

Ядро концепту DOG представлено лексемою $d o g$ в англійській мові. До основних способів номінації концепту DOG в англійській мові уналежнюємо іменники на кшталт рup, puppy, doggy, mongrel, hound. У тезаурусі Роже (Roget's II The New Thesaurus) концепт DOG репрезентовано такими одиницями: ядро - puppy-dog, pup, puppy, hound,canine: ближню периферію представлено словами: cur, tyke, mongrel, pariah dog, mutt; до крайньої периферії входять такі лексеми: watch-dog, house-dog, banddog, policedog, whippet, courser; lurcher, harrier, beagle,gamedog, gun-dog, retriever, pointer, setter, terrier, showdog, toydog, pug-dog, Pekinese,poodle, husky, sledge-dog, wilddog, dingo, wolf, coyote.

The Synonym Finder містить такі одиниці концепту DOG: ядро-canid, canine, domestic animal, domesticated animal зі значенням «a member of the genus Canis (probably descended from the common wolf) that has been domesticated by man since prehistoric times; occurs in many breeds»; ближня периферія представлена такими одиницями - chap, blighter, bloke, fella, feller, fellow, gent, lad, cuss зі значенням «informal term for a man», також до ближньої периферії уналежнено одиницю frump зі значеннями «a dull unattractive unpleasant girl or woman»; cad, blackguard, 
bounder, heel, hound» та «someone who is morally reprehensible»; крайню периферію реалізовано за допомогою лексем andiron, dog-iron, firedog зі значенням «metal supports for logs in a fireplace» ma pawl, dog, detent, click зі значенням «a hinged catch that fits into a notch of a ratchet to move a wheel forward or prevent it from moving backward».

Аналіз синонімічних репрезентантів імені концепту DOG дав змогу представити номінативне поле концепту у такий спосіб: ядро концепту представлене лексемою $d o g$; ближня периферія охоплює лексеми рup, puppy, hound, canine, cur, tyke, mongrel, watch-dog, house-dog, toydog, Pekinese, poodle, husky, sledge-dog, wilddog, dingo, wolf, coyote. До дальньої периферії уналежнено chap, blighter, bloke, fella, feller, fellow, gent, lad, cuss, beast, bleeder, blighter, bastard, frump.

\section{5. Вербалізація концептів $C A T$ і $D O G$ лексичними одиницями}

Іменами зооконцептів CAT i DOG постають англійські лексеми cat та $\operatorname{dog}$, оскільки саме вони концентрують у вербальній оболонці узагальнене уявлення про цих тварин, а також їх зараховано до основного рівня категоризації, який є особливо значущим для повсякденної свідомості.

Під час аналізу концептів CAT i DOG виявлено, що зазначені концепти можуть бути експліковані в мові за допомогою прямих та непрямих номінацій.

У межах прямої репрезентації концепти CAT і DOG можуть бути репрезентовані, по-перше, іменниками, зокрема: імена концептів САТ i DOG. До периферійної репрезентації уналежнюємо номінації за гендерною (a bitch - у назвах тварин означає самку) та віковою ознакою (найменування дитинчат тварин) - a kitten (кошеня), а рирру (иуценя), а також емоційно навантажені номінації (a pussycat - сором'язливий чоловік, спокуслива жінка; сору саt - людина, яка всіх копіює; alley cat жінка легкої поведінки).

По-друге, концепти CAT i DOG можуть бути репрезентовані за допомогою номінацій за такими характеристиками як зовнішня (тобто за зовнішньою ознакою - розмір / порода / забарвлення) (a lapdog - декоративна собака; a mongrel - дворняжка, a poodle - nyдель, husky хаскі, terrier-тер'єр, Pотеranian dog - померанський шпиць, pugdogмопс, German shepherd - німецька вівчарка, Labrador - лабрадор, maltese dog - мальтійська болонка, bulldog - бульдог, badger-dog - 
такса, Dobermann - доберман, Siamеsе саt - сіамська кішка, leорагd cat - бенгальська кішка, Persian саt-nерсидська кішка, Burтеse cat бурма, Egyptian Cat - єгипетський мау, Maine Coon cat - мейн кун; серед номінацій щодо забарвлення тварини виявлено такі приклади: white - білий, gray - сірий, black - чорний, red-pудий, smoky - димчастий, three-colored - триколірний, spotted - плямистий, striped - смугастий), так і функційна ( a barker - брехлива собака, a hound, hunting $\operatorname{dog}$ - мисливський собака, a watchdog сторожовий пес). Сюди ж зараховуємо власні імена (клички) собак, які репрезентують для носіїв мови тварину (Cerberus). Серед периферії диференціюємо прикметники зі значенням родової віднесеності / приналежності тварини (feline котячий, canine - собачий).

До непрямої репрезентації концептів CAT і DOG належать такі лексеми: дієслова (to bark, bow-wow - гавкати, to yelp - скиглити, howlвити, gnar - гарчати, yell-верещати, whinner - скиглити, sniff-coniти, фиркати, sniff-обнюхати) і вигуки (тіaоw, теоw-мяу, bow-wow, woof-woof - гав-гав), що позначають характерні дії тварин; прикметники, які виокремлюють конкретні якості / ознаки тварин (mangy паршивий (собака), кудлатий (собака) - shaggy, кульгаючий (собака) laте, скажений (собака) - таd, відданий (собака) - devotee, scald, wretched-паскудна (кішка), граціозна (кішка) - graceful, лагідна (кішка) - affectionate, пухнаста (кішка) - fluffy, грайлива (кішка) - playful хитра (кішка) - cunning), семантично пов'язані з позначуваними тваринами іменники (a kennel - собача будка) i, зокрема, їх збірні номінації ( $a$ pack of dogs - зграя собак), метонімічні найменування частини тварини (a fang - клик).

Непряма репрезентація інколи може проявитися не зі словникової дефініції, а на рівні етимологічного аналізу, а також залучення додаткових екстралінгвістичних знань: to foil (esp. In hunting, to run over or cross (the ground, scent, or track) with the effect of baffling the hounds - збивати собаку зі сліду, to coffee-house = to gossip, to indulge in gossip (пліткувати) < Originally of fox hunters while waiting for the hounds to find a fox! to draw a covert, etc., during a fox-hunt (nроходuтu крізь хащзі в пошуках дичини під час полювання на лисищь). На прикладі вище вказаних виразів стає зрозумілим те, що пошук етимологічних ознак потребує додаткових історичних та екстралінгвістичних відомо- 
стей. Можливо, що асоціації з зооконцептом підтримувалися лише на певному етапі історичного існування висловлювань. Під час непрямої реалізації мовна пам'ять, крім позамовних уявлень й етимологічних відомостей, додатково пожвавлюється зв'язком 3 іншими мовними утвореннями, в яких концепт експлікований безпосередньо.

Прикладами прямої репрезентації концептів CAT i DOG можуть бути такі лексеми: a mouser: 1) an animal that catches mice; esp. applied to a cat, or an owl. A cat good at catching mice; 2) (slang) a detective; a non-starter: 1) a non-starter in a race is a horse or dog that cannot or will not start; 2) one who does not start something; esp. one who fails to start in a race or othercontest; hence, a useless or ineffective person or thing; a chit: 1) the young of a beast; whelp, cub; kitten, puppy; 2) applied, more or less contemptuously, to a child, esp. a very young child. A person considered as no better than a child; now, mostly of a girl or young woman.

Випадки непрямої репрезентації представлено такими одиницями: to $\mathrm{waul} / \mathrm{wawl}=$ to utter the loud harsh/plaintive cry characteristic of cats or of newborn babies; to dock: 1) to shorten (the tail of a horse, dog, etc.) by cutting off one or more of the extreme caudal vertebra; 2) to make a deduction from (a person's pay) as a fine, subscription, etc.

Крім того, зафіксовано випадок метонімічної репрезентації концептів. Цей випадок представлено одним прикладом: a fang 1) a canine tooth; a tusk. The tooth of a wolf, dog, etc; 2) in various transferred uses.

Отже, проведений аналіз дає змогу визначити особливості лексичного вираження концептів CAT i DOG. За нашими спостереженнями досліджувані концепти можуть бути експліковані в англійській мові не лише прямими номінантами (cat, dog, canine, feline, bitch, puppy, kitten та ін.), а й непрямими (to bark, to yelp, fang, kennel та ін.). Вивчення концептів CAT i DOG за допомогою їхньої лексичної вербалізації в англійській мові виявило значущість досліджуваних концептів для англійської лінгвокультури, що підтверджується великою кількістю мовних засобів, використовуваних для номінації та опису концептів CAT i DOG. Однак, незважаючи на велику варіативність репрезентантів досліджуваних концептів, мовні засоби передають тільки частину того глобального поняття, що існує в свідомості. 


\section{6. Висновки}

Концепти відбивають стереотипи та культурні переконання певного народу. Вони виникають у процесі набуття знань та отримання інформації не лише про навколишню дійсність, а й про об'єкти уявних світів. Концепти CAT i DOG репрезентують універсальне явище, що має культурно марковані особливості актуалізації в англійській лінгвокультурі. Концепти CAT і DOG - номіновані концепти, для яких характерна загальновідома мовна репрезентація словами або фразово. Зазначені концепти є сформованими, тобто такими, формування інтразони (сукупність асоціацій, що входять до концепту) яких вже завершилося (але екстразона продовжує функціонувати (сукупність асоціацій, що виникають у зв'язку 3 концептом)).

Поняттєвий складник концептуальної структури визначається на основі дефініційного та компонентного аналізів. Унаслідок дефініційного аналізу та спираючись на визначення номінативної лексеми cat $i \operatorname{dog}$ y 7 тлумачних словниках, виокремлюємо 12 узагальнених значень, що утворюють денотат досліджуваного концепту САТ та 14 узагальнених значень, що продукують денотат концепту DOG. Поняттєву основу концептів CAT i DOG розширено за допомогою додаткових семантичних ознак, визначених з урахуванням когнітивно-семантичного аналізу синонімічних відповідників іменників cat ma dog. Вербальні номінації, що репрезентують концепти САТ i DOG, інтерпретуємо як фіксатори фрагментів знань про об'єкти, експліцитно виражені мовним матеріалом. Концепти CAT i DOG мають конкретно-предметний характер, тобто співвідносяться 3 предметною реалією - дискретним, об'єктивно наявним матеріальним об'єктом дійсності. Етимологічні характеристики концептів $є$ певним вихідним етапом аналізу змістовного мінімуму концептів CAT i DOG, який представлений у словниковій дефініції та є основою для визначення структури семантичного простору, завдяки іменам цих концептів. Спільним для ЛО cat i dog є їх давньогерманське походження, що свідчить про довгу історію їх функціонування в англійській мові. 


\section{Список літератури:}

1.Бєлєхова Л. И. (2005). Современная лингвистика в Украине и мире: научные парадигмы, наработки и перспективы. Науковий вісник ХДУ. Серія «Лінгвістика». Херсон: 8-15.

2. Воробйова О. П. (2011). Концептологія в Україні: здобутки, проблеми, прорахунки. Вісник КНЛУ. Сер. Філологія. Київ: 53-64.

3. Карасик В. И. (2001). Лингвокультурный концепт как единица исследования. Методологические проблемы когнитивной лингвистики. Воронеж : 75-80.

4. Степанов Ю. С. (1997). Константы. Словарь русской культуры. Опыт исследования. Москва: 824.

5. Субиркина Н. Ю. (2011). Дискурс в аспекте диахронической концептологии (на материале исследования концепта «честь»). Вестник МГЛУ. Москва: 43-52.

6. Cambridge international dictionary of English: Guides you to the meaning (2000). New York: 1775.

7. Collins English dictionary (2000). London: 1785.

8. Collins English Dictionary \& Thesaurs (2007). Glasgow: 1397.

9. Hornby A. S. (1982). Oxford advanced learner's dictionary of current English. Moscow: 509.

10. The Oxford dictionary of English etymology (1985). Oxford: 1025.

\section{References:}

1. Bjeljehova L. Y. (2005). Sovremennaja lingvistika v Ukraine i mire: nauchnye paradigmy, narabotki i perspektivy [Modern linguistics in Ukraine and the world: scientific paradigms, developments and prospects]. Naukovyj visnyk HDU. Serija «Lingvistyka». Kherson: 8-15.

2. Vorobjova O. P. (2011). Konceptologija v Ukraini: zdobutky, problemy, prorahunky [Conceptology in Ukraine: achievements, problems, miscalculations]. Visnyk KNLU. Ser. Filologija. Kyiv: 53-64.

3. Karasik V. I. (2001). Lingvokul'turnyj koncept kak edinica issledovanija [Linguocultural concept as a unit of research]. Metodologicheskie problemy kognitivnoj lingvistiki. Voronezh: 75-80.

4. Stepanov Ju. S. (1997). Konstanty. Slovar' russkoj kul'tury. Opyt issledovanija [Constants. Dictionary of Russian culture. Research experience]. Moskow: 824. (in Russian)

5. Subirkina N. Ju. (2011). Diskurs v aspekte diahronicheskoj konceptologii (na materiale issledovanija koncepta «chest'») [Discourse in the aspect of diachronic conceptology (based on the study of the concept of «honor»)]. Vestnik MGLU. Moskow: 43-52.

6. Cambridge international dictionary of English: Guides you to the meaning (2000). New York: 1775.

7. Collins English dictionary (2000). London: 1785.

8. Collins English Dictionary \& Thesaurs (2007). Glasgow: 1397.

9. Hornby A. S. (1982). Oxford advanced learner's dictionary of current English. Moscow: 509.

10. The Oxford dictionary of English etymology (1985). Oxford: 1025. 